\title{
ELECTRODEPOSITION OF CO-DOPED HYDROXYAPATITE COATING ON 316L STAINLESS STEEL
}

\author{
Vo Thi Hanh ${ }^{1,2}$, Pham Thi Nam ${ }^{3}$, Nguyen Thu Phuong ${ }^{3}$, Dinh Thi Mai Thanh ${ }^{1,4}$ \\ ${ }^{1}$ Graduate University of Science and Technology, VAST, 18 Hoang Quoc Viet, Cau Giay, Ha Noi \\ ${ }^{2}$ Hanoi University of Mining and Geology, 18 Pho Vien, Duc Thang, Bac Tu Liem, Ha Noi \\ ${ }^{3}$ Institute for Tropical Technology, VAST, 18 Hoang Quoc Viet, Cau Giay, Ha Noi \\ ${ }^{4}$ University of Science and Technology of Hanoi, VAST, 18 Hoang Quoc Viet, Cau Giay, Ha Noi \\ "Email:vothihanh2512@gmail.com
}

Received: 10 June 2017; Accepted for publication: 17 December 2017

\begin{abstract}
Hydroxyapatite (HAp) co-doped by magnesium (Mg), strontium ( $\mathrm{Sr}$ ), sodium (Na) and fluorine (F) was deposited on the 316L stainless steel (316L SS) substrate by electrodeposition method. The influences of scanning potential ranges, scanning times, scanning rates to form MgSrFNaHAp coating were investigated. The analytical results of FTIR, SEM, Xray, EDX, thickness and adhension of the obtained coating at scanning potential ranges of $0 \div-$ $1.7 \mathrm{~V} / \mathrm{SCE}$; scaning times of 5 , scanning rate of $5 \mathrm{mV} / \mathrm{s}$ showed that MgSrFNaHAp coatings were single phase crystals of HAp, exhibiting rod shape with the thickness of $8.9 \mu \mathrm{m}$ and the adhesion strength reaching $8.38 \mathrm{MPa}$.
\end{abstract}

Keywords: 316L stainless steel, electrodeposition, MgSrFNaHAp.

Classification numbers: $2.7 .1 ; 2.10 .1$.

\section{INTRODUCTION}

HAp is applied in medical implant field because of its structure and biological activity similar to the natural bone [1]. HAp coating also protects for the metal surfaces against corrosion in the biological environment and prevents the release of metal ions from the substrates into the environment. However, pure HAp can be dissolved in the physiological environment which may lead to the disintegration of the coating and affect the implant fixation [2]. Thus, to reduce the dissolution and to further improve the biocompatibility of HAp coating, the trace elements were incorporated in the HAp structure.

Sodium in HAp has important roles to increase the bone metabolism and stimulate the bone cell growth [3, 4]. Magnesium is one of the most important elements in the formation of bone tissue, the stimulation of the osteoblast proliferation and bone strength structure [1,5]. Strontium has been considered an essential trace element for the human body. Strontium plays a special role in promoting osteoblast growth and inhibiting bone resorption [6]. Fluorine exists in the 
natural bone and tooth tissue as an essential element which can improve the crystallization and the mineralization of calcium phosphate for new bone formation [2].

The electrochemical deposition (ED) of HAp or HAp doped on metal or alloy surfaces has become an important technology for various applications due to it has many advantages such as the low temperature, controlling the thickness coating, the high purity, high bonding strength and low cost of the equipment. Furthermore, it is easy to substitute other ions into hydroxyapatite coating by ED.

Until now, there have been many studies about HAp coating and HAp coating doped by single ions using ED but HAp coating co-doped by some ions existed in natural born are hardly reported. In this study, HAp coatings co-doped by $\mathrm{Mg}^{2+}, \mathrm{Sr}^{2+}, \mathrm{Na}^{+}$and $\mathrm{F}^{-}$ions were carried out by the cathodic scanning potential method with different synthesis conditions such as scanning potential ranges, reaction temperature, scanning rate and scanning times.

\section{EXPERIMENTAL}

\subsection{Electrodepositon of MgSrFNaHAp coatings}

$316 \mathrm{~L} \mathrm{SS}(0.27 \%$ of $\mathrm{Al} ; 0.17 \%$ of $\mathrm{Mn} ; 0.56 \%$ of $\mathrm{Si} ; 17.98 \%$ of $\mathrm{Cr} ; 9.34 \%$ of $\mathrm{Ni}$; $2.15 \%$ of Mo; $0.045 \%$ of $\mathrm{P} ; 0.035 \%$ of $\mathrm{S}$ and $69.45 \%$ of $\mathrm{Fe}$ ) was used as the substrates and a cathode for the experiments. It was polished with $\mathrm{SiC}$ papers, rinsed ultrasonically in distilled water for 15 minutes, then dried at room temperature and limited the working area to $1 \mathrm{~cm}^{2}$ by the epoxy.

MgSrFNaHAp coatings were synthesized on the $316 \mathrm{~L}$ SS by cathode scanning potential method with a three-electrode cell fitted: 316L SS as the working electrode; platinum foil electrode acting as the counter electrode and a saturated calomel electrode (SCE) as the reference electrode.

MgSrFNaHAp coatings were deposited in $\mathrm{SMgSrFNa}$ solution containing: $3 \times 10^{-2} \mathrm{M}$ $\mathrm{Ca}\left(\mathrm{NO}_{3}\right)_{2}+1.8 \times 10^{-2} \mathrm{M} \mathrm{NH}_{4} \mathrm{H}_{2} \mathrm{PO}_{4}+6 \times 10^{-2} \mathrm{M} \mathrm{NaNO}_{3}+2 \times 10^{-3} \mathrm{M} \mathrm{NaF}+5 \times 10^{-4} \mathrm{M} \mathrm{Mg}\left(\mathrm{NO}_{3}\right)_{2}+$ $2.8 \times 10^{-6} \mathrm{M} \mathrm{Sr}\left(\mathrm{NO}_{3}\right)_{2}$ at $50{ }^{\circ} \mathrm{C}$ with the different conditions as follows: the scanning potential ranges: 0 to $-1.5,-1.7,-1.9$ and $-2.1 \mathrm{~V} / \mathrm{SCE}$; scanning times: 3, 4, 5, 6, 7 and 10 times; scanning rates: $3,4,5,6$ and $7 \mathrm{mV} / \mathrm{s}$.

\subsection{Coating characterization}

The functional groups of MgSrFNaHAp coatings were analyzed by Fourier transform infrared (FTIR - Nicolet 6700) spectroscopy with the range of $4000-400 \mathrm{~cm}^{-1}$, using the $\mathrm{KBr}$ pellet technique. The morphology of the coatings was characterized using scanning electron microscopy (SEM - Hitachi S4800). The composition of elements in MgSrFNaHAp coatings was identified by energy-dispersive X-ray spectroscopy (EDS - JSM 6490/JED 1300 Jeol). The phase structure of the MgSrFNaHAp coatings on the 316L SS was analyzed by X-ray diffraction (SIEMENS D5005 Bruker-Germany). The mass of MgSrFNaHAp deposited on the surface of 316L SS was determined by the mass change of 316L SS samples before and after the synthesis. The thickness of the coatings was measured following the standard of ISO 4288-1998 by AlphaStep IQ system (KLA-Tencor-USA). The charge was determined by taking the integral from the start to the end point of the cathodic polarization curve. The adhesion strength of MgSrFNaHAp coatings on 316L SS substrate was examined using an automatic adhesion tester (PosiTest ATA, DeFelsko) according to ASTM D-4541 standard [8]. 


\section{RESULTS AND DISCUSSION}

\subsection{Effect of the scanning potential range}

The cathodic polarization curve of 316L SS electrode in SMgSrFNa solutions is shown in Fig. 1. With the potential range of $0 \div-0.7 \mathrm{~V} / \mathrm{SCE}$, the value of the current density is approximately zero because there is no reaction occuring on 316L SS substrate. With the potential of $-0.6 \div-1.2 \mathrm{~V} / \mathrm{SCE}$, the current density increases slightly due to the reduction of $\mathrm{O}_{2}$ to produce $\mathrm{OH}^{-}$[7]. When potential is more negative than $-1.2 \mathrm{~V} / \mathrm{SCE}$, the current density increases fast because several electrochemical reactions are suggested, such as: the reduction of $\mathrm{NO}_{3}^{-}, \mathrm{H}_{2} \mathrm{PO}_{4}^{-}, \mathrm{H}_{2} \mathrm{O}$ to produce $\mathrm{OH}^{-}, \mathrm{PO}_{4}^{3-}$ and $\mathrm{H}_{2}[7,9,10]$. The increase in concentration of $\mathrm{OH}^{-}$results in the increase $\mathrm{pH}$ around the surface of cathode and leading the acid-base reaction of $\mathrm{H}_{2} \mathrm{PO}_{4}^{-}$and $\mathrm{OH}^{-}$forms $\mathrm{PO}_{4}^{3-}[7,9]$. Then the precipitation reaction of $\mathrm{PO}_{4}^{3-}$ with $\mathrm{Ca}^{2+}, \mathrm{Na}^{+}$, $\mathrm{Mg}^{2+}, \mathrm{Sr}^{2+}$ and $\mathrm{F}^{-}$produces MgSrFNaHAp on the cathode substrate according to the chemical reaction:

$$
\begin{aligned}
& 10\left(\mathrm{Ca}^{2+}, \mathrm{Na}^{+}, \mathrm{Mg}^{2+}, \mathrm{Sr}^{2+}\right)+6 \mathrm{PO}_{4}{ }^{3-}+2 \mathrm{OH}^{-} \rightarrow(\mathrm{Ca}, \mathrm{Na}, \mathrm{Mg}, \mathrm{Sr})_{10}\left(\mathrm{PO}_{4}\right)_{6}(\mathrm{OH})_{2} \\
& (\mathrm{Ca}, \mathrm{Na}, \mathrm{Mg}, \mathrm{Sr})_{10}\left(\mathrm{PO}_{4}\right)_{6}(\mathrm{OH})_{2}+\mathrm{x} \mathrm{F}^{-} \rightarrow \mathrm{Ca}_{10}\left(\mathrm{PO}_{4}\right)_{6}(\mathrm{OH})_{2-\mathrm{x}} \mathrm{F}_{\mathrm{x}}+\mathrm{x} \mathrm{OH}^{-}
\end{aligned}
$$

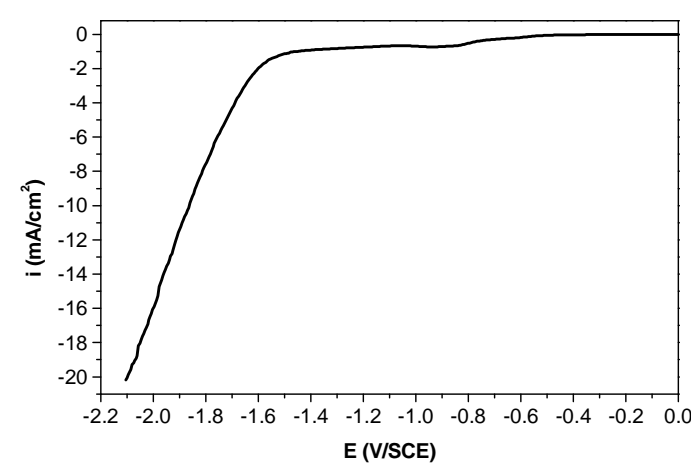

Figure 1. The cathodic polarization curve of 316L SS electrode.

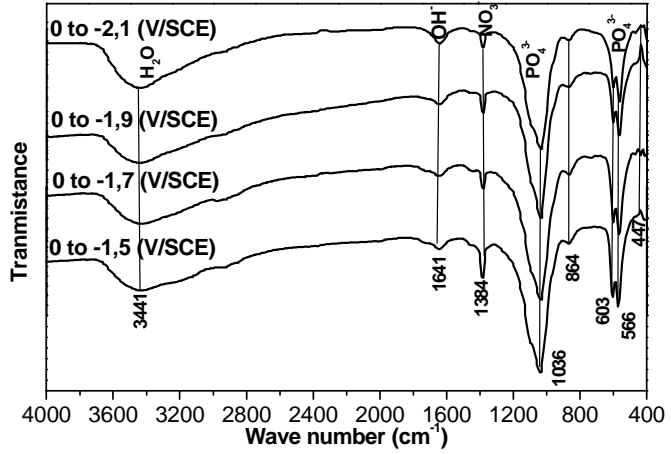

Figure 2. FTIR spectra of MgSrFNaHAp coatings synthesized at the different scanning potential ranges.

Based on the cathodic polarization curve, MgSrFNaHAp coatings were synthesized with different scanning potential ranges: $0 \div-1.5 ; 0 \div-1.7 ; 0 \div-1.9 ; 0 \div-2.1 \mathrm{~V} / \mathrm{SCE}$. Fig. 2 shows the FTIR spectra of obtained coatings at the wavenumber range from $4000 \mathrm{~cm}^{-1}$ to $400 \mathrm{~cm}^{-1}$. There are some characteristic peaks of HAp: peaks of $\mathrm{PO}_{4}^{3-}$ group at 1036; 603; 566 and $447 \mathrm{~cm}^{-1}$; the vibration of $\mathrm{OH}^{-}$at 3441 and $1641 \mathrm{~cm}^{-1}$. Furthermore, the peak of $\mathrm{NO}_{3}^{-}$is also observed at 1384 $\mathrm{cm}^{-1}$ because $\mathrm{NO}_{3}^{-}$ions are present at the solution. The peak of $\mathrm{CO}_{3}^{2-}$ is detected at $864 \mathrm{~cm}^{-1}$. It could be explained that the $\mathrm{CO}_{2}$ from in the air could be dissolved in the electrolyte and reacts with $\mathrm{OH}^{-}$to form the $\mathrm{CO}_{3}^{2-}$ ions.

Table 1 shows the charge, mass and the thickness of MgSrFNaHAp coating formed on 316L SS with different potential ranges. The charge increases from 1.18 to $8.34 \mathrm{C}$ when the scanning potential range extends from $0 \div-1.5$ to $0 \div-2.1 \mathrm{~V} / \mathrm{SCE}$. Therefore, according to Faradays law, $\mathrm{OH}^{-}$and $\mathrm{PO}_{4}^{3-}$ ions are formed more so the mass of obtained coatings increases. 
However, the mass and thickness of MgSrFNaHAp coatings increases and reaches the maximum value at potential range of $0 \div-1.7 \mathrm{~V} / \mathrm{SCE}\left(3.15 \mathrm{mg} / \mathrm{cm}^{2}\right.$ and $\left.8.9 \mu \mathrm{m}\right)$. With the more negative potential range, these values decrease. The results are explained by the charge increases with the negative scanning potential range, so the amount of $\mathrm{OH}^{-}$and $\mathrm{PO}_{4}^{3-}$ ions on the electrode surface increases leading to the diffusion of them into the solution to form MgSrFNaHAp powder. Moreover, with the more negative potential range, the adhension strength between the coatings and 316L SS substrate decreases and the obtained coatings are porous because of hydrogen bubbles formation on the electrode surface. Thus, the potential range of $0 \div-1.7$ V/SCE is chosen for the next experiments.

Table 1. The variation of charge, mass, thickness and adhesion strength of obtained coating at different scanning potential ranges.

\begin{tabular}{|c|c|c|c|c|}
\hline $\begin{array}{c}\text { Potential range } \\
(\mathrm{V} / \mathrm{SCE})\end{array}$ & Charge $(\mathrm{C})$ & $\begin{array}{c}\text { MgSrFNaHAp mass } \\
\left(\mathrm{mg} / \mathrm{cm}^{2}\right)\end{array}$ & $\begin{array}{c}\text { Thickness } \\
(\mu \mathrm{m})\end{array}$ & $\begin{array}{c}\text { Adhesion strength } \\
(\mathrm{MPa})\end{array}$ \\
\hline $0 \div-1.5$ & 1.18 & 1.21 & 3.7 & 8.79 \\
\hline $0 \div-1.7$ & 3.89 & 3.15 & 8.9 & 8.38 \\
\hline $0 \div-1.9$ & 5.20 & 2.07 & 6.5 & 7.64 \\
\hline $0 \div-2.1$ & 8.34 & 1.57 & 4.6 & 6.52 \\
\hline
\end{tabular}

\subsection{Effect of scanning times}

The XRD diffraction data of MgSrFNaHAp coatings deposited at different scanning times are shown in Fig. 3. The results show that the scanning times have an effected on the hydroxyapatite phase. With the scanning times from 1 to 3 , the obtained phase is mostly dicalcium phosphate dehydrate $\left(\mathrm{CaHPO}_{4} \cdot 2 \mathrm{H}_{2} \mathrm{O}, \mathrm{DCPD}\right)$ with the typical peak at $2 \theta$ of $12^{\circ}$. DCPD is formed due to the reaction between $\mathrm{Ca}^{2+}$ and $\mathrm{HPO}_{4}{ }^{2-}$ [7]. With scanning times from 5 to 10 scans, MgSrFNaHAp coatings exhibit the hydroxyapatite phase. It can be explained that because the scanning times rise, the charge increases leading to more formation of $\mathrm{OH}^{-}$. The amount of $\mathrm{OH}^{-}$ions is enough to transform completely $\mathrm{H}_{2} \mathrm{PO}_{4}^{-}$to $\mathrm{PO}_{4}^{3-}[7,9], \mathrm{HPO}_{4}^{2-}$ ions are not sufficient to carry out the reaction forming DCPD, so the obtained coatings were singlephase of HAp. Thus, according to all results above, 5 scanning times is chosen for MgSrFNaHAp coatings electrodeposition.

Table 2 shows the charge, mass, thickness and adhesions of MgSrFNaHAp coating obtained at the scanning times from 1 to 10 . With one scanning time, the charge is $0.78 \mathrm{C}$, the adhesion strength reaches the highest value $(12.81 \mathrm{MPa})$. This value is approximately with the adhesion of the glue and substrates (15 MPa). This is explained that because mass and thickness of deposited coatings are small $\left(0.62 \mathrm{mg} / \mathrm{cm}^{2}\right.$ and $\left.1.8 \mu \mathrm{m}\right)$, so it is not enough to cover all surface of the substrate, leading to the obtained adhesion strength by the contributed of substrate and glue. The charge of deposited process increases according to scanning times. However, the mass and thickness of coatings only increase with scanning times increasing from 3 to 5 scans. Then, these values decrease if the increasing of the scanning times is number larger. The adhesion strength has opposite change rule with charge. The adhesion decreases from 12.81 to 6.72 $\mathrm{MPa}$ when scanning times increases from 1 to 10 scans. It is explained that the charge 
increases leading to the much formation of $\mathrm{OH}^{-}$and $\mathrm{PO}_{4}{ }^{3-}$ ions on the electrode surface and diffusing into the solution so MgSrFNaHAp powder is formed in the solution without adhesion on the substrate.

Based on the above results, 5 scanning times is chosen for the deposition of MgSrFNaHAp coatings.

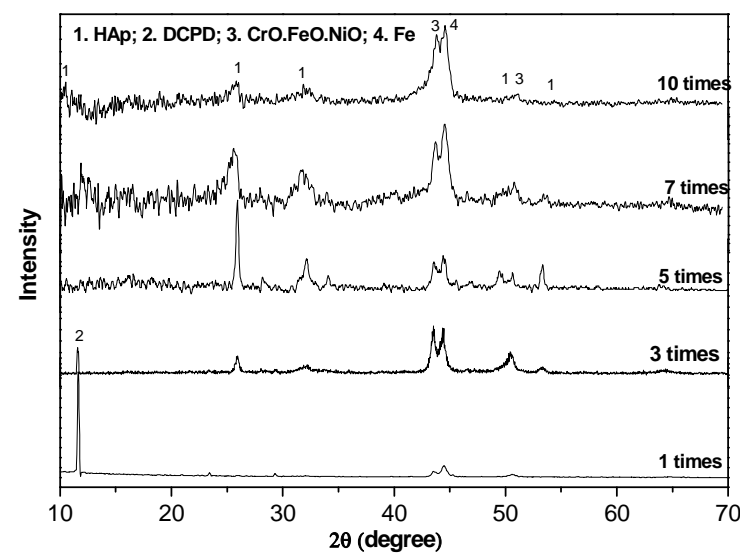

Figure 3. XRD patterns of MgSrFNaHAp/316L SS synthesized at the different scanning times.

Table 2. The variation of charge, mass, thickness and adhesion strength of MgSrFNaHAp coatings to 316L SS at the different scanning times.

\begin{tabular}{|c|c|c|c|c|}
\hline $\begin{array}{c}\text { Scanning times } \\
\text { (times) }\end{array}$ & Charge $(\mathrm{C})$ & $\begin{array}{c}\text { MgSrFNaHAp mass } \\
\left(\mathrm{mg} / \mathrm{cm}^{2}\right)\end{array}$ & $\begin{array}{c}\text { Thickness } \\
(\mu \mathrm{m})\end{array}$ & $\begin{array}{c}\text { Adhesion } \\
\text { strength }(\mathrm{MPa})\end{array}$ \\
\hline 1 & 0.78 & 0.62 & 1.8 & 12.81 \\
\hline 3 & 2.45 & 1.87 & 6.3 & 9.86 \\
\hline 5 & 3.89 & 3.17 & 8.9 & 8.38 \\
\hline 7 & 4.48 & 2.9 & 8.4 & 7.61 \\
\hline 10 & 5.55 & 2.37 & 7.1 & 6.72 \\
\hline
\end{tabular}

\subsection{Effect of scanning rate}

Figure 4 presents the XRD patterns of MgSrFNaHAp coatings synthesized in different scanning rates. XRD patterns show the hydroxyapatite phase with the typical peaks at $2 \theta$ of $32^{\circ}$ (211) and $26^{\circ}(002)$. However, with the scanning rate of 6 and $7 \mathrm{mV} / \mathrm{s}$, there are also peaks of DCPD at $2 \theta$ of $12^{\circ}$. It can be explained that the charge decreases with high scanning rate leading to the insufficient formation of $\mathrm{OH}^{-}$to transform completely $\mathrm{HPO}_{4}{ }^{2-}$ into $\mathrm{PO}_{4}{ }^{3-}$ so DCPD formed.

Table 3 shows the charge, mass, thickness and adhesions of obtained coatings with scanning rate increasing from 3 to $7 \mathrm{mV} / \mathrm{s}$. With scanning rate increasing from 3 to $5 \mathrm{mV} / \mathrm{s}$, the charge decreases from 5.86 to $3.80 \mathrm{C}$, but the mass of obtained coatings and the adhesion of coating rise. The scanning rate continues to increase to 6 and $7 \mathrm{mV} / \mathrm{s}$, so the charge decreases from 3.41 and $2.58 \mathrm{C}$, the mass and thickness consequenlly decrease, but the adhesion increases. The results can be explained that with the slow scanning rate, the large charge, the amount of 
$\mathrm{OH}^{-}$and $\mathrm{PO}_{4}^{3-}$ ions formed on the surface is more, leading to the creation of MgSrFNaHAp powder in the solution; In addiction, because of the hydrogen bubbles formation, the coating is porous and has low adhesion. Thus, scanning rate of $5 \mathrm{mV} / \mathrm{s}$ is chosen for the deposition of $\mathrm{MgSrFNaHAp} \mathrm{coatings.}$

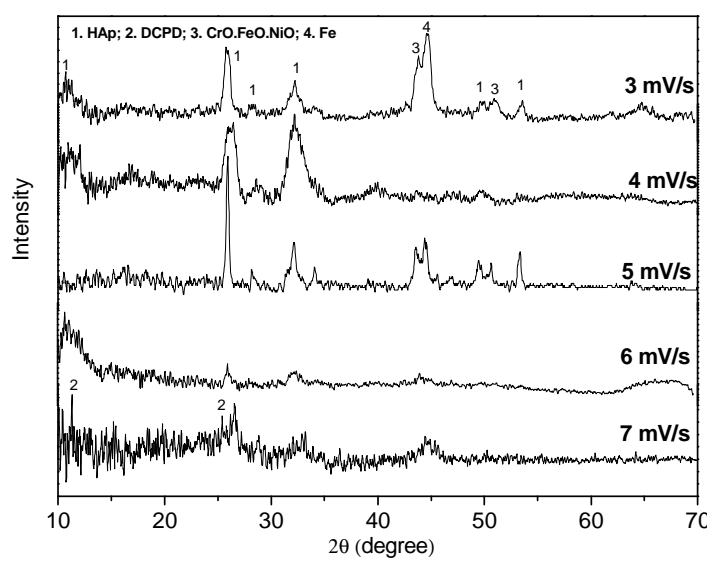

Figure 4. XRD patterns of MgSrFNaHAp/316L SS synthesized at the different scanning rate.

Table 3. The variation of charge, mass, thickness and adhesion strength of HAp coatings to 316L SS at different scanning rate.

\begin{tabular}{|c|c|c|c|c|}
\hline $\begin{array}{c}\text { Scanning rate } \\
(\mathrm{mV} / \mathrm{s})\end{array}$ & Charge $(\mathrm{C})$ & $\begin{array}{c}\text { MgSrFNaHAp mass } \\
\left(\mathrm{mg} / \mathrm{cm}^{2}\right)\end{array}$ & $\begin{array}{c}\text { Thickness } \\
(\mu \mathrm{m})\end{array}$ & $\begin{array}{c}\text { Adhesion } \\
\text { strength }(\mathrm{MPa})\end{array}$ \\
\hline 3 & 5.86 & 1.26 & 5.5 & 5.23 \\
\hline 4 & 4.57 & 2.13 & 7.1 & 6.67 \\
\hline 5 & 3.80 & 3.17 & 8.8 & 8.38 \\
\hline 6 & 3.41 & 1.94 & 6.2 & 8.85 \\
\hline 7 & 2.58 & 1.25 & 4.0 & 9.15 \\
\hline
\end{tabular}

\subsection{Characterization of MgSrFNaHAp coating}

The MgArFNaHAp coatings synthesized in $\mathrm{SMgSrFNa}$ solution at $50{ }^{\circ} \mathrm{C}$, with the scanning times of 5 , scanning rate of $5 \mathrm{mV} / \mathrm{s}$, and the scanning potential ranges of $0 \div-0.7 \mathrm{~V} / \mathrm{SCE}$ are characterized by EDX and SEM.

\section{* The components of MgSrFNaHAp coatings}

The components of obtained MgSrFNaHAp coatings are analyzed by the EDX spectra. There is the presence of 7 main elements in the MgSrFNaHAp including: $\mathrm{Ca}, \mathrm{O}, \mathrm{P}, \mathrm{Mg}, \mathrm{Na}, \mathrm{F}$ and Sr. The content of these elements in coatings is shown in Table 4. These results have been used to calculate the atomic ratios of $\mathrm{M} / \mathrm{Ca},(\mathrm{Ca}+\mathrm{M}) / \mathrm{P}$ (Table 5). The ratios suggest that the components of the elements in the coatings are in within the limits of them in natural bone [11]. 
Thurs, the obtained coatings have the similar composition to the mineral phase in natural bone and could be applied to produce the implant materials.

Table 4. The component of content of MgSrFNaHAp coating synthesized on 316L SS.

\begin{tabular}{|c|c|c|}
\hline Element & Weigh (\%) & Atomic (\%) \\
\hline $\mathrm{O}$ & 49.34 & 68.20 \\
\hline $\mathrm{P}$ & 15.76 & 11.20 \\
\hline $\mathrm{Ca}$ & 32.65 & 18.00 \\
\hline $\mathrm{Na}$ & 0.58 & 0.99 \\
\hline $\mathrm{Mg}$ & 0.14 & 0.13 \\
\hline $\mathrm{Sr}$ & 0.03 & 0.01 \\
\hline $\mathrm{F}$ & 1.50 & 1.47 \\
\hline Total & 100 & 100 \\
\hline
\end{tabular}

Table 5. The atomic ratios of M/P in MgSrFNaHAp coatings and in natural bone.

\begin{tabular}{|c|c|c|c|c|c|}
\hline Atomic ratios & $\mathrm{F} / \mathrm{Ca}$ & $\mathrm{Mg} / \mathrm{Ca}$ & $\mathrm{Sr} / \mathrm{Ca}$ & $\mathrm{Na} / \mathrm{Ca}$ & $(\mathrm{Ca}+\mathrm{Mg}+\mathrm{Sr}+0.5 \mathrm{Na}) / \mathrm{P}$ \\
\hline MgSrFNaHAp coatings & 0.131 & 0.012 & $8.93 .10^{-4}$ & 0.088 & 1.664 \\
\hline Natural bone [11] & 0.149 & 0.018 & $9.76 .10^{-4}$ & 0.102 & 1.67 \\
\hline
\end{tabular}

\section{* SEM images}

SEM images of obtained coating are shown in Fig. 5. At the same conditions, $\mathrm{MgSrFNaHAp} \mathrm{coatings} \mathrm{with} \mathrm{the} \mathrm{presence} \mathrm{of} \mathrm{Mg}, \mathrm{Sr}, \mathrm{F}$ are highly dense, uniform and have a rod shape, while HAp coatings have a plate shape.
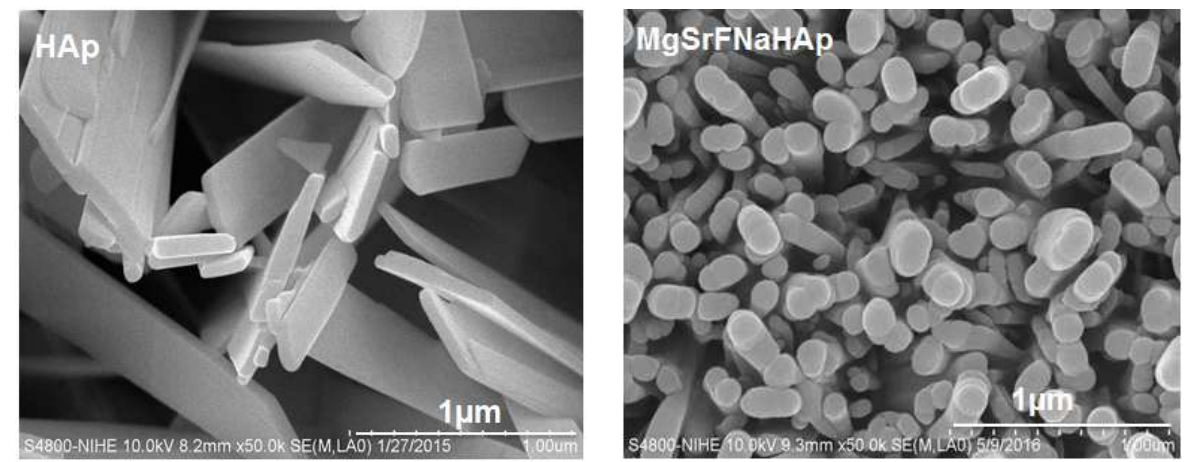

Figure 5. The SEM images of HAp and MgSrFNaHAp coatings obtained at the same conditions.

\section{CONCLUSION}

$\mathrm{Mg}, \mathrm{Sr}, \mathrm{F}, \mathrm{Na}$ are incorporated into HAp coating on 316L SS by electrodeposition. The best condition to deposited coatings is at scanning potential ranges of $0 \div-1.7 \mathrm{~V} / \mathrm{SCE}$, scanning times 
of 5 , scanning rates of $5 \mathrm{mV} / \mathrm{s}$, in $\mathrm{SNgSrFNa}$ solutions. The present of these trace elements with the limited components in natural bone, the MgSrFNaHAp coatings become denser, so could protect better for the substrates than HAp coating. With these good characteristics, $\mathrm{MgSrFNaHAp} \mathrm{coatings} \mathrm{can} \mathrm{be} \mathrm{applied} \mathrm{to} \mathrm{produce} \mathrm{good} \mathrm{implant} \mathrm{materials.}$

\section{REFERENCES}

1. Sharifnabi, Fathi, Eftekhari Yekta, Hossainalipour - The structural and bio-corrosion barrier performance of $\mathrm{Mg}$-substituted fluorapatite coating on 316L stainless steel human body implant. Applied Surface Science 288 (2014) 331-340.

2. Yong Huang, Yajing Yan, Xiaofeng Pang - Electrolytic deposition of fluorine-doped hydroxyapatite $/ \mathrm{ZrO}_{2}$ films on titanium for biomedical applications. Ceramics International 39 (1) (2013) 245-253.

3. Hejun Li, Xueni Zhao, Sheng Cao, Kezhi Li, Mengdi Chen, Zhanwei Xu, Jinhua Lu, Leilei Zhang - Na doped hydroxyapatite coating on carbon/carbon composites: Preparation, in vitro bioactivity and biocompatibility. Applied Surface Science 263 (2012) 163-173.

4. Zhang Leilei, Li Hejun, Li Kezhi, Zhang Shouyang, Fu Qiangang, Zhang Yulei, Lu Jinhua, Li Wei - Preparation and characterization of carbon/SiC nanowire/Na-doped carbonated hydroxyapatite multilayer coating for carbon/carbon composites. Applied Surface Science 313 (2014) 85-92.

5. Bakhsheshi, Rad, Hamzah, Daroonparvar, Yajid, Kasiri Asgarani, Abdul Kadir, Medraj - Invitro degradation behavior of $\mathrm{Mg}$ alloy coated by fluorine doped hydroxyapatite and calcium deficient hydroxyapatite. Transactions of Nonferrous Metals Society of China $\mathbf{2 4}$ (8) (2014) 2516-2528.

6. Boyd, Rutledge, Randolph, Meenan - Strontium-substituted hydroxyapatite coatings deposited via a co-deposition sputter technique. Materials Science and Engineering 46 (2015) 290-300.

7. Pham Thi Nam, Dinh Thi Mai Thanh, Nguyen Thu Phuong, Le Xuan Que, Nguyen Van Anh, Thai Hoang, Tran Dai Lam - Controlling the electrodeposition, morphology and structure of hydroxyapatite coating on 316L stainless steel. Materials Science and Engineering 33( 4) (2013) 2037-2045.

8. Standard Test Method for Pull-Off Strength of Coating Using Portable Adhension Testers Astm D-4541, Annual Book of Astm Standards, American Society for Testing and Materials, Philadelphia, Pa, USA, 2002.

9. Qiongqiong Dinga, Yajing Yan, Yong Huang, Shuguang Hana, Xiaofeng Pang - Magnesium substituted hydroxyapatite coating on titanium with nanotublar $\mathrm{TiO}_{2}$ intermediate layer via electrochemical deposition. Applied Surface Science 305 (2014) 77-85.

10. Jian Wang, Yonglie Chao, Qianbing Wan, Zhimin Zhu, Haiyang Yu - Fluoridated hydroxyapatite coatings on titanium obtained by electrochemical deposition. Acta Biomaterialia 5 (5) (2009) 1798-1807.

11. Bowen Humphry John Moule- Environmental Chemistry of the Element, London, Academic Press, Inc 1979. 